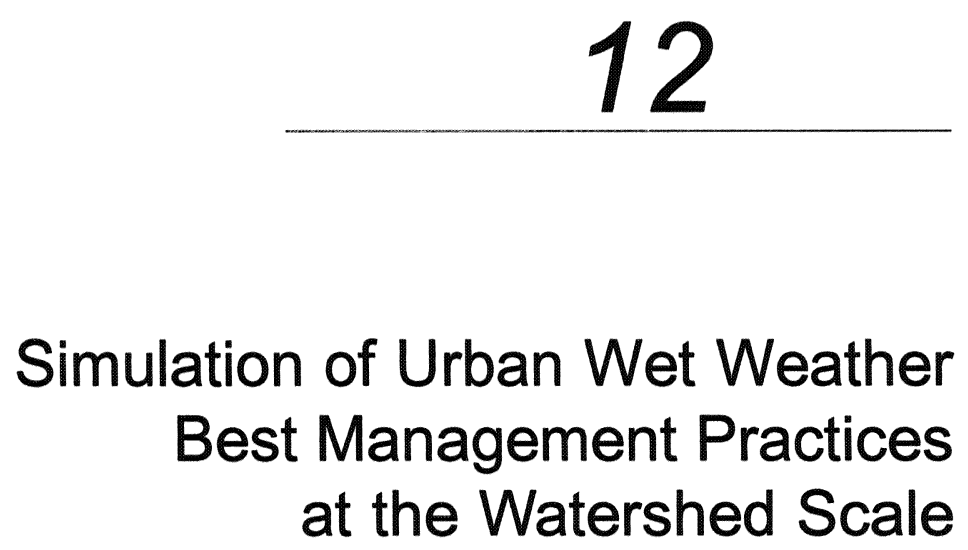

R. Dwayne Myers, Mark Maimone, James Smullen and Brian Marengo

\title{
12.1 Background
}

\subsubsection{Comprehensive Watershed Planning and Management}

While water resources planning on a watershed basis has become the preferred approach on both the Federal and State level, much of the planning and implementation of watershed plans will continue to occur on a more local level. The numerical analyses discussed in this chapter are part of a comprehensive watershed planning program underway in southeastern Pennsylvania. The goal of the Southeastern Pennsylvania Waterways Restoration Program (SPWRP) is to regain the resources in and around streams that were lost due to urbanization, both within the City of Philadelphia and in the surrounding counties.

The regulatory context of watershed planning is complex. The watershed planning approach being developed is intended to meet requirements of five major regulatory programs. These are:

1. the requirements of section 303(d) of the Clean Water Act Amendments to improve water quality on impaired water bodies;

Myers, D., M. Maimone, J. Smullen and B.G. Marengo. 2004. "Simulation of Urban Wet Weather Best Management Practices at the Watershed Scale." Journal of Water Management Modeling R220-12. doi: 10.14796/JWMM.R220-12.

(c) CHI 2004 www.chijournal.org ISSN: 2292-6062 (Formerly in Innovative Modeling of Urban Water Systems. ISBN: 0-9683681-9-0) 
2. the Phase I and Phase II National Pollutant Discharge Elimination System (NPDES) stormwater regulations to control pollution due to discharges from municipal and industrial stormwater systems;

3. Commonwealth of Pennsylvania Act 537 Sewage Facilities Planning to protect and prevent contamination of groundwater and surface water by developing proper sewage disposal plans;

4. Commonwealth of Pennsylvania Storm Water Management Act 167 to address management of stormwater runoff quantity and quality in developing areas; and

5. the U.S. National Combined Sewer Overflow (CSO) Control Policy.

Some of the data collection and analyses are common to more than one program. The SPWRP provided an integrated watershed management approach that effectively met the requirements of each program without duplication of effort.

This chapter presents a case study for the Cobbs Creek watershed, an urban watershed draining approximately 22 square miles $\left(35 \mathrm{~km}^{2}\right)$ in southeastern Pennsylvania. Analysis of available GIS data indicates that approximately $50 \%$ of the drainage area is covered by impervious surfaces, including roads, parking lots, and rooftops. About $20 \%$ of the total area is served by a combined sewer system, $75 \%$ is served by separate storm sewer systems, and $5 \%$ is unsewered. Because the watershed is highly developed, the potential for new development is limited. The Cobbs Creek watershed is a complex system that provides ample opportunities to develop and demonstrate a comprehensive watershed management program in an urban environment.

\subsubsection{Role of Structural BMPs}

In a highly urbanized environment where a large percentage of the land surface consists of roads, parking lots, rooftops, driveways, and other impervious surfaces, complete restoration of natural flow patterns in the urban streams is usually impractical. Structural best management practices (BMPs) incorporated in redevelopment offer the primary opportunity to reduce runoff volume and pollutant loads while slowing the rate of stormwater releases to the sewers and streams in existing urban areas. Redevelopment offers the best opportunity to demonstrate innovative approaches to CSO control, improved stormwater management, and stream corridor improvement. Modeling offers the best tool to demonstrate how effective new approaches to site stormwater design can be. 
Incorporating structural BMPs in urban redevelopment addresses a number of technical and socioeconomic goals:

- demonstrating a commitment to meeting the spirit and the letter of the new approaches to stormwater management encouraged by regulatory agencies;

- saving significant costs associated with the more traditional "big tank" or "pond" approach to CSO and separate stormwater control; and

- demonstrating the effectiveness of these approaches and making similar projects more likely to occur in the future.

The US EPA's Storm Water Management Model (SWMM) was used to evaluate the operational characteristics and benefits of structural BMPs in the SPWRP because it is suitable to the hydrologic and hydraulic complexity of the system (Huber and Dickinson, 1992; Roesner et al., 1988) and provides the capability to simulate the operation of most structural options under consideration.

\subsection{Modeling BMP Hydraulic Mechanisms at the Watershed Scale}

\subsubsection{Hydraulic Mechanisms (General)}

Construction of the model framework was accomplished by envisioning different types of BMPs as hydraulic systems which remove, detain, and release stormwater using a set of common processes. Many of the processes affecting stormwater runoff quality and quantity are directly linked to these hydraulic processes. Five principal processes were identified:

- storage,

- infiltration,

- evaporation and/or transpiration (ET),

- slow release through an orifice, riser, weir, or porous media, and

- overflow or bypass flow.

The release from a real structure typically is more complex than simply a slow release and an overflow. Perforated riser pipes, weirs, valves, and gates often are designed to provide intermediate release rates. However, while the simplification of a slow release and an overflow pathway may not be representative enough of all hydraulic processes to support micro-scale designs for a single facility, it is acceptable at the watershed meso-scale in long-term continuous simulation. 
To model BMPs at the watershed scale, an element was placed at the outlet of each subshed representing the combined area and volume of BMPs in the subshed. Hydrograph timing was not a problem because the model subsheds are relatively small and impervious, typically exhibiting short times of concentration. Appropriate areas and volumes, shown in Figure 12.1, were determined from a combination of best professional judgment based on experience and literature, including data from the ASCE/EPA National BMP Database.

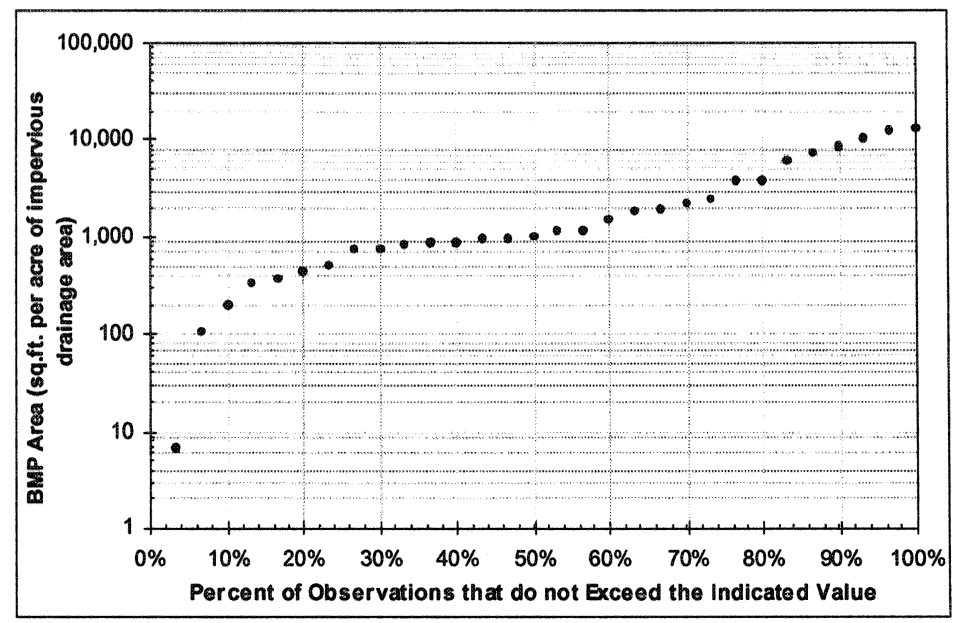

Figure 12.1 Cumulative distribution of surface area in national BMP database (ASCE/EPA).

\subsubsection{Hydraulic Mechanisms in Selected BMPs}

Table 12.1 illustrates how the five processes apply in various combinations to different BMP types. The following discussion of five of the BMP types selected for study illustrates their similarities and differences from a hydraulic perspective:

Infiltration Basins. An infiltration basin typically makes use of all five processes and is considered the most general case. It provides storage volume and removes stormwater through both evaporation and infiltration. Where soil conditions do not permit infiltration of all standing water within a prescribed period of time, the infiltration basin releases water to the receiving water. A large pipe or spillway provides an overflow relief when a large storm exceeds the capacity of the storage volume. The water that is detained and released 
Table 12.1 BMP hydraulic mechanisms.

$\mathrm{X}=$ generally applicable

$\mathrm{X}^{*}=$ applicable under some circumstances

blank cell $=$ not applicable

Urban Wet Weather Best Management Practices

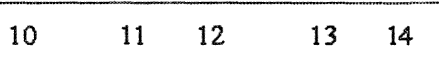

Reduce Porous Dry Residential Infiltration Rain Dry Wet Swales/Open Sand Green Wetlands CSO RTC Pavement Pavement Wells Dry Wells Basins Barrels Detention Retention Channels Filters' Roofs Tanks Along Bio-

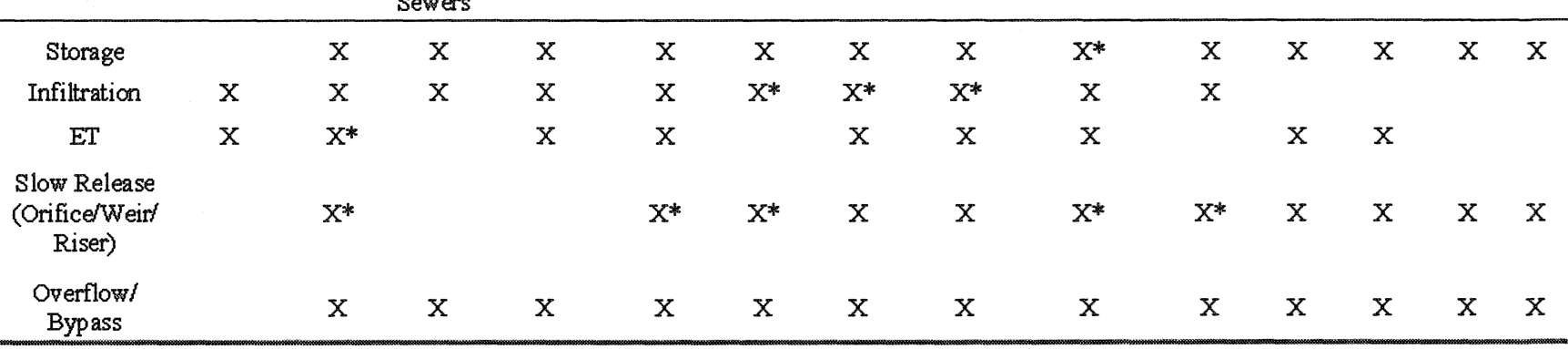

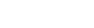

(2) 
slowly receives a measure of water quality treatment for certain parameters, while concentrations of constituents in the overflow will be similar to untreated runoff.

Porous Media Filters. A sand filter, while different in structure and scale from an infiltration basin, also may make use of the same five processes. In this case, the storage volume is provided in the pore spaces between soil grains, and the slow release mechanism is the resistance to flow caused by the porous media itself.

Porous Pavement. Porous pavement is used most often as an infiltration mechanism in areas where soil is well drained. The volume of storage may be increased by increasing the depth of the gravel sub-base. In areas with less welldrained soil, slow release and overflow mechanisms may also be added to the design if needed.

Green Rooftops. Green rooftops do not allow any infiltration into the ground itself and function primarily by delaying runoff through storage routing and reducing volumes through ET. Pore spaces in the growing medium provide storage, and additional storage may be provided by an underdrain consisting of gravel or a synthetic material. A slow release mechanism is sometimes included in the design depending on how effective ET is at removing the volume stored in the soil pores. An overflow mechanism is necessary for storms that exceed the storage capacity of the system.

CSO Tanks and Real Time Control. By storing, detaining, and slowly releasing wet weather flows in an area served by combined or separate storm sewers, the hydraulic grade line may be kept more often at a level that does not cause overflows or reduce release rates. The hydraulic mechanisms of online or offline storage tanks are conceptually similar to a detention basin: they provide a static storage volume, a slow release, and an unrestricted overflow. Similar results may be obtained through real time control, where a system of adjustable gates, weirs, or dams takes advantage of dynamic routing and timing characteristics to manage flow and head in the sewer.

\subsection{BMP Modeling Approaches in SWMM}

\subsubsection{Approaches using SWMM RUNOFF}

Table 12.2 summarizes several approaches to simulating the meso-scale operation of 14 types of BMPs in SWMM RUNOFF. The most elementary is the conversion of a portion of the impervious area to pervious area, or a 
Table 12.2 Approaches to BMP modeling using SWMM RUNOFF.

\begin{tabular}{|c|c|c|c|c|c|c|c|c|c|c|c|c|c|}
\hline & \multicolumn{13}{|c|}{ Urban Wet Weather Best Management Practices } \\
\hline & 1 & 2 & 3 & 4 & 5 & 6 & 7 & 8 & 9 & 10 & 11 & 12 & 1314 \\
\hline & $\begin{array}{l}\text { Reduce } \\
\text { Pavement }\end{array}$ & $\begin{array}{l}\text { Porous } \\
\text { t Pavement }\end{array}$ & $\begin{array}{l}\text { Dry } \\
\text { twells } \\
\text { Along } \\
\text { Storm } \\
\text { Sewers }\end{array}$ & $\begin{array}{l}\text { Residential } \\
\text { Dry Wells } \\
\end{array}$ & $\begin{array}{l}1 \text { Infiltration } \\
\text { Basins }\end{array}$ & $\begin{array}{l}\text { Rain } \\
\text { Barrels }\end{array}$ & $\begin{array}{l}\text { Dry } \\
\text { Detention }\end{array}$ & $\begin{array}{l}\text { Wet } \\
\text { Retention }\end{array}$ & $\begin{array}{l}\text { Swales'Open } \\
\text { Channels }\end{array}$ & $\begin{array}{l}\text { Sand } \\
\text { Filters/ } \\
\text { Bio- } \\
\text { retention }\end{array}$ & $\begin{array}{l}\text { Green } \\
\text { Roofs }\end{array}$ & Wetlands & $\begin{array}{l}\text { ls CSO RTC } \\
\text { Tanks }\end{array}$ \\
\hline $\begin{array}{l}\text { change impervious } \\
\text { area to pervious }\end{array}$ & $\mathrm{X}$ & $\mathrm{X}^{*}$ & $X^{*}$ & $\mathrm{X}^{*}$ & $\mathrm{X}^{*}$ & $X^{*}$ & $\mathrm{X}^{*}$ & $X^{*}$ & $\mathrm{X}^{*}$ & $\mathrm{X}^{*}$ & $\mathrm{X}^{*}$ & & \\
\hline $\begin{array}{l}\text { route impervious to } \\
\text { pervious with } \\
\text { detention storage }\end{array}$ & $\mathrm{X}$ & & $\mathrm{X}$ & $\mathrm{X}$ & $\mathrm{X}$ & & $\mathrm{X}$ & $\mathrm{x}$ & $X^{*}$ & $\mathrm{X}$ & $\mathrm{X}^{*}$ & $\mathrm{X}^{*}$ & \\
\hline $\begin{array}{l}\text { groundwater } \\
\text { routine }\end{array}$ & $\mathrm{X}^{*}$ & $\mathrm{X}$ & $\mathrm{X}^{*}$ & $\mathrm{X}^{*}$ & $\mathrm{X}^{*}$ & & & & $X^{*}$ & $\mathrm{x}$ & & $\mathrm{X}$ & \\
\hline $\begin{array}{c}\text { channel w/ } \\
\text { downstream control }\end{array}$ & & & $\mathrm{X}^{*}$ & & & $\mathrm{X}^{*}$ & $X^{*}$ & $\mathrm{X}^{*}$ & $\mathrm{X}^{*}$ & & $\mathrm{X}^{*}$ & $X^{*}$ & $\mathrm{X}^{*}$ \\
\hline $\begin{array}{c}\text { specialized } \\
\text { SWMMM/PCSWMM } \\
\text { subroutine }\end{array}$ & & $X$ & & & & & & & & & & & \\
\hline
\end{tabular}

\section{LEGEND}

$\mathrm{X}=$ generally applicabl

$\mathrm{X}^{*}=$ applicable under some circum stance

bl ank cell $=$ not applicable 
reduction in the watershed impervious area directly connected to the drainage system. This method is reasonable, for example, if the sizes of driveways are reduced during redevelopment. It may be reasonable for a relatively small impervious area (e.g. a suburban roof) discharging onto a relatively large pervious area (e.g. a suburban lawn). It is most likely not appropriate and will overestimate the benefit of a large impervious area (e.g. a mall parking lot) discharging to a small pervious area (e.g. a bioretention basin).

The second line in Table 12.2 refers to options available in SWMM RUNOFF that allow routing of runoff from an impervious area to a pervious area. An example of this approach will be presented in a later section.

The SWMM RUNOFF code includes a groundwater algorithm that may be used to model BMPs where infiltration is significant, such as infiltration basins, sand filters, and bioretention. In addition, PCSWMM has a specialized subroutine for modeling porous pavement (James and James, 2001). These approaches are included for completeness, but will not be discussed in detail.

\subsubsection{Approaches using SWMM STORAGE/TREATMENT and TRANSPORT}

The STORAGE module of SWMM originally was designed to simulate wastewater treatment plants and is capable of simulating the five principal BMP processes shown in Table 12.3. A storage element can be created with a given volume, orifices and weirs, pumps, and an overflow. It is not necessary to assume that a node in STORAGE is completely mixed because a reservoir routing method can be applied. Water quality constituents can be simulated if desired. However, if the element is not large enough for routing to be of concern, and if water quality is not simulated, STORAGE has few advantages over EXTRAN. Stirrup and Marchant (2002) pointed out that STORAGE does not have features for simulation of dynamic real time control elements, including head-dependent gates and pumps.

The TRANSPORT module of SWMM is capable of simulating a combined sewer system, including transport of water quality constituents. This may be desirable in some situations where water quality at specific points in the collection system is of concern. However, TRANSPORT does not simulate surcharge and other complex hydraulic conditions at the level of detail that the EXTRAN module does. The goal of the current study is to simulate the hydrologic and hydraulic effects of BMPs distributed throughout a complex watershed and collection system that includes both combined sewered and separate sanitary sewered areas, and to extend those results to estimate pollutant loads. 
Table 12.3 Approaches to BMP modeling using SWMM STORAGE/TREATMENT.

\begin{tabular}{|c|c|c|c|c|c|c|c|c|c|c|c|c|c|c|}
\hline & \multicolumn{14}{|c|}{ Urban Wet Weather Best Management Practices } \\
\hline & 1 & 2 & 3 & 4 & 5 & 6 & 7 & 8 & 9 & 10 & 11 & 12 & 13 & 14 \\
\hline & $\begin{array}{l}\text { Reduce } \\
\text { Pavement }\end{array}$ & $\begin{array}{l}\text { Porous } \\
\text { t Pavement }\end{array}$ & $\begin{array}{l}\text { Dry } \\
\text { Wells } \\
\text { Along } \\
\text { Storm } \\
\text { Sewers }\end{array}$ & $\begin{array}{l}\text { Residential } \\
\text { Dry Wells }\end{array}$ & $\begin{array}{l}1 \text { Infiltration } \\
\text { Basins }\end{array}$ & $\begin{array}{l}\text { Rain } \\
\text { Barrels }\end{array}$ & $\begin{array}{l}\text { Dry } \\
\text { Detention }\end{array}$ & $\begin{array}{l}\text { Wet } \\
n \text { Retention }\end{array}$ & $\begin{array}{l}\text { Swales/Open } \\
\text { n Channels }\end{array}$ & $\begin{array}{l}\text { Sand } \\
\text { Filters/ } \\
\text { Bio- } \\
\text { retention }\end{array}$ & $\begin{array}{l}\text { Green } \\
\text { Roofs }\end{array}$ & Wetlands & $\begin{array}{l}\text { s CSO } \\
\text { Tanks }\end{array}$ & ${ }_{S}^{R T C}$ \\
\hline $\begin{array}{l}\text { create new } \\
\text { nodes } \\
\text { representing } \\
\text { BMPs }\end{array}$ & & $\mathrm{x}$ & $\mathrm{x}$ & $\mathrm{x}$ & $\mathrm{x}$ & $\mathrm{X}$ & $\mathrm{X}$ & $\mathrm{X}$ & $X^{*}$ & $\mathrm{x}$ & $\mathrm{X}$ & $\mathrm{X}$ & $\mathrm{X}$ & $\mathrm{X}^{*}$ \\
\hline $\begin{array}{c}\text { constant } \\
\text { evaporation / } \\
\text { infiltration }\end{array}$ & & $\mathrm{X}$ & $\mathrm{X}$ & $x$ & $\mathrm{X}$ & & $x$ & $\mathrm{X}$ & $X^{*}$ & $\mathrm{x}$ & $\mathrm{x}$ & $\mathrm{X}$ & & \\
\hline $\begin{array}{l}\text { orifice control } \\
\text { (slow release) }\end{array}$ & & $\mathrm{X}$ & & & $\mathrm{x}$ & $\mathrm{X}$ & $\mathrm{X}$ & $\mathrm{x}$ & $\mathrm{X}^{*}$ & $\mathrm{x}$ & $\mathrm{x}$ & $\mathrm{x}$ & $\mathrm{X}$ & $x$ \\
\hline $\begin{array}{l}\text { weir controls } \\
\text { (bypass) }\end{array}$ & & $X$ & $\mathrm{X}$ & $x$ & $x$ & $x$ & $X$ & $X$ & $\mathrm{x}$ & $\mathrm{x}$ & $\mathrm{X}$ & $x$ & $x$ & $x$ \\
\hline $\begin{array}{l}\text { reserv oir } \\
\text { routing for } \\
\text { large storage } \\
\text { elements }\end{array}$ & & $\mathrm{X}$ & $\mathrm{X}^{*}$ & & $X$ & & $X$ & $x$ & $X$ & & & $x$ & $x$ & $\mathrm{X}$ \\
\hline
\end{tabular}

\footnotetext{
LEGEND

$\mathrm{X}=$ generally applicable

$\mathrm{X}^{*}=$ applicable under some circumstances

blank cell $=$ not applicable
} 


\subsubsection{Approaches using SWMM EXTRAN}

Table 12.4 summarizes approaches to modeling 14 types of BMPs using SWMM EXTRAN. The first option adds storage to an existing node, a convenient option when modeling structural storage options like tanks for CSO control. For instance, the most direct way to represent storage at a regulator structure in EXTRAN is to maintain the existing regulator structure elevations while increasing surface area, or storage volume per unit of elevation, to provide the desired storage.

Many other BMP types may be represented by adding an additional node upstream of the existing stream or sewer inlet. EXTRAN provides enough flexibility to add a node with storage, a constant withdrawal representing infiltration and evaporation, an orifice or equivalent pipe representing a slow release, and a large pipe providing an unrestricted overflow. An example of this approach is provided later in this chapter.

EXTRAN commonly is used to simulate combined sewers and real time control as a CSO control measure. A system of gates, weirs, and inflatable dams that respond to flow or depth of flow conditions in the system may be represented by the range of variable orifice and pump types available in EXTRAN. For example, a variable orifice can simulate the effects of gate openings on the hydraulic grade line at a downstream wet well, or at any other point in the system. Pump curves can approximate more complex behavior where a flow rate depends on head within a particular junction. Finally, EXTRAN also is appropriate in cases where operator judgment may be needed to adjust system settings independent of flow- or head-based logic, for example based on a weather forecast. A model run can be halted, flow and head conditions saved at all points in the system, the appropriate settings changed, and the model restarted using the saved conditions.

\subsection{Case Study}

\subsubsection{Watershed Description}

This section presents a case study for the Cobbs Creek watershed, an urban watershed draining approximately 22 square miles $\left(35 \mathrm{~km}^{2}\right)$ in southeastern Pennsylvania. Analysis of available GIS data indicates that approximately $50 \%$ of the drainage area is covered by impervious surfaces, including roads, parking lots, and rooftops. Based on SWMM calibration results and analysis of 
Table 12.4 Approaches to BMP modeling using SWMM EXTRAN.

\begin{tabular}{|c|c|c|c|c|c|c|c|c|c|c|c|c|c|c|}
\hline & \multicolumn{14}{|c|}{ Urban Wet Weather Best Management Practices } \\
\hline & 1 & 2 & 3 & 4 & 5 & 6 & 7 & 8 & 9 & 10 & 11 & 12 & 13 & 14 \\
\hline & $\begin{array}{l}\text { Reduce } \\
\text { Pavement }\end{array}$ & $\begin{array}{l}\text { Porous } \\
\text { t Pavement }\end{array}$ & $\begin{array}{l}\text { Dry } \\
\text { t Wells } \\
\text { Along } \\
\text { Storm } \\
\text { Sewers }\end{array}$ & $\begin{array}{l}\text { Residential } \\
\text { Dry Wells }\end{array}$ & $\begin{array}{l}1 \text { Infiltration } \\
\text { Basins }\end{array}$ & $\begin{array}{l}\text { Rain } \\
\text { Barrels }\end{array}$ & $\begin{array}{l}\text { Dry } \\
\text { s Detention }\end{array}$ & $\begin{array}{l}\text { Wet } \\
\text { aetention }\end{array}$ & $\begin{array}{l}\text { Swales/ } \\
\text { Open } \\
\text { Channels }\end{array}$ & $\begin{array}{l}\text { Sand } \\
\text { Filters' } \\
\text { Bio- } \\
\text { retention }\end{array}$ & $\begin{array}{l}\text { Green } \\
\text { Roofs }\end{array}$ & Wetlands & $\begin{array}{l}\text { CSO } \\
\text { Tanks }\end{array}$ & RTC \\
\hline $\begin{array}{l}\text { add storage to } \\
\text { existing nodes (e.g. } \\
\text { CSO regul ators) }\end{array}$ & & $\mathrm{X}^{*}$ & $x$ & $\mathrm{X}$ & $x$ & $\mathrm{X}$ & $\mathrm{X}$ & $\mathrm{X}$ & $\mathrm{X}^{*}$ & $\mathrm{x}$ & $\mathrm{x}$ & $\mathrm{X}$ & $\mathrm{x}$ & $\mathrm{x}$ \\
\hline $\begin{array}{l}\text { create new nodes } \\
\text { representing BMPs }\end{array}$ & & $\mathrm{X}^{*}$ & $x$ & $\mathrm{x}$ & $\mathrm{x}$ & $\mathrm{x}$ & $\mathrm{x}$ & $\mathrm{x}$ & $\mathrm{X}^{*}$ & $\mathrm{x}$ & $x$ & $\mathrm{x}$ & $\mathrm{x}$ & $\mathrm{x}$ \\
\hline $\begin{array}{l}\text { constant outflow } \\
\text { from BMP node }\end{array}$ & & $X^{*}$ & $x$ & $x$ & $x$ & & $\mathrm{X}$ & $\mathrm{X}$ & $\mathrm{X}^{*}$ & $\mathrm{X}$ & $X$ & $X$ & & $x$ \\
\hline $\begin{array}{l}\text { new evaporation } \\
\text { option }\end{array}$ & & $\mathrm{X}^{*}$ & & & $\mathrm{X}$ & & $x$ & $x$ & $\mathrm{X}^{*}$ & $X^{*}$ & $x$ & $X$ & & \\
\hline $\begin{array}{l}\text { pump water out of } \\
\text { BMP node }\end{array}$ & & $\mathrm{X}^{*}$ & $x$ & $\mathrm{X}$ & $x$ & $x$ & $\mathrm{X}$ & $\mathrm{X}$ & $X^{*}$ & $x$ & $x$ & $X$ & $\mathrm{X}$ & $x$ \\
\hline $\begin{array}{l}\text { small orifice/pipe } \\
\text { from BMP node }\end{array}$ & & $\mathrm{X}^{*}$ & & & $x$ & $x$ & $\mathrm{X}$ & $X$ & $X^{*}$ & $X^{*}$ & $X$ & $x$ & $X$ & $x$ \\
\hline $\begin{array}{l}\text { overflow/bypass } \\
\text { pipe from BMP } \\
\text { node }\end{array}$ & & $X^{*}$ & $X$ & $X$ & $x$ & $\mathrm{X}$ & $\mathrm{X}$ & $X$ & $X$ & $X$ & $\mathrm{X}$ & $\mathrm{X}$ & $\mathrm{X}$ & $X$ \\
\hline $\begin{array}{l}\text { dynamic orifices } \\
\text { (varying with time } \\
\text { and/or head) }\end{array}$ & & $\mathrm{X}^{*}$ & & & $\mathrm{X}^{*}$ & & $X^{*}$ & $\mathrm{X}^{*}$ & & & & $X^{*}$ & $X^{*}$ & $\mathrm{X}$ \\
\hline
\end{tabular}

LEGEND

$\mathrm{X}=$ generally applic able; $\mathrm{X}^{*}=$ applicable under some circum stances; bl ank cell $=$ not applicable 


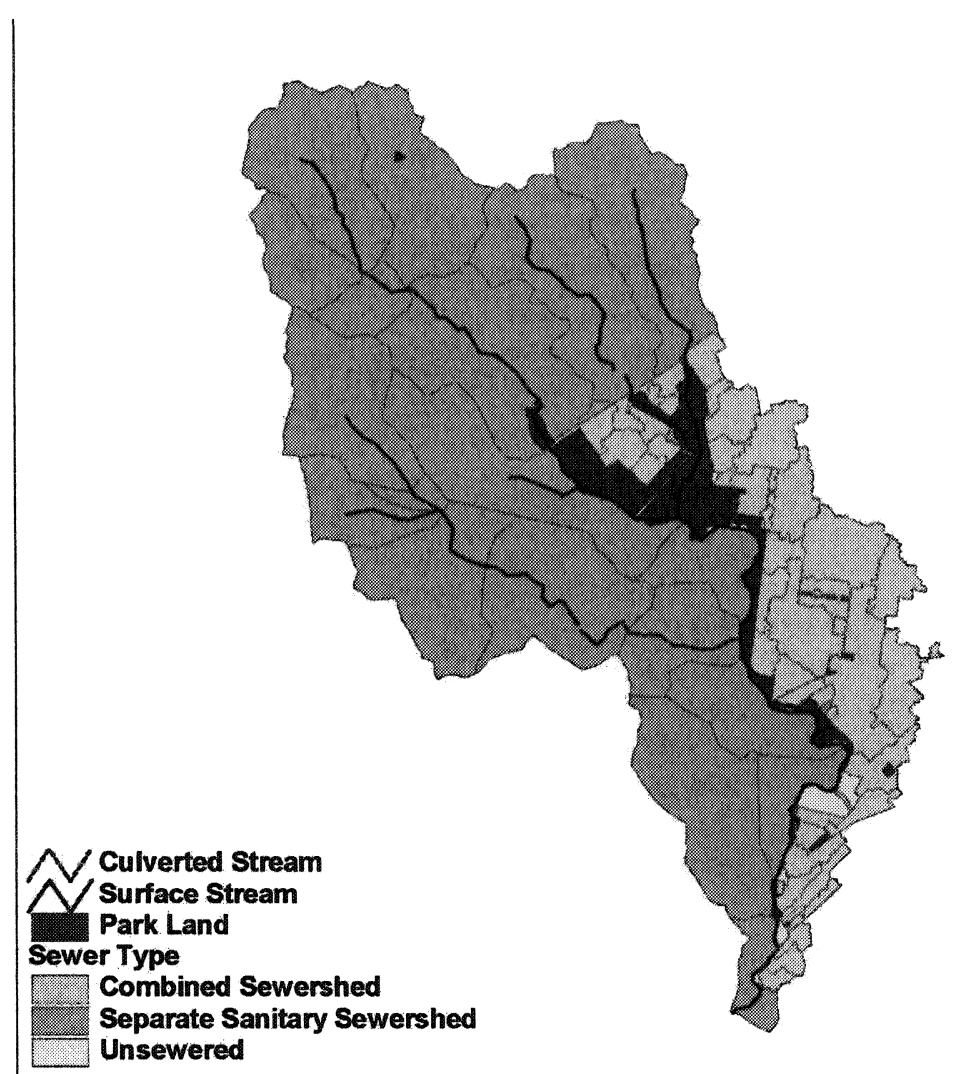

Figure 12.2 Cobbs Creek Watershed.

precipitation and streamflow records, between $40 \%$ and $75 \%$ of this impervious cover is directly connected to the sewer system (directly connected impervious area, DCIA). The largest differences between total and effective impervious area occur in the northern, more suburban portions of the watershed, while the smallest differences occur in the most heavily urbanized areas.

The southeastern portion of the area shown in Figure 12.2, or about $20 \%$ of the total area, is served by a combined sewer system. Except for park lands (about $5 \%$ of the drainage area), the rest of the watershed is served by separate storm sewer systems. Many of the riparian areas are public park lands. Natural soils present in the watershed include silty loams, but most of the soil present is urban fill material that has not been studied extensively. The limited data 
available suggest that this fill material may have hydraulic characteristics similar to sandy silt. Because the watershed is significantly developed, the potential for new development is limited. The Cobbs Creek watershed is a complex system that provides ample opportunities to develop and demonstrate a comprehensive watershed management program in an urban environment.

\subsubsection{Watershed Model Description}

The foundation of the current study is a comprehensive hydrologic and hydraulic model of the watershed including a sub-model of the combined sewer system (EXTRAN) and its tributary area (RUNOFF), and a RUNOFF representation of the drainage area tributary to the areas served by separate storm sewer systems. The stream system itself is modeled using EXTRAN, with open channels representing the natural stream cross sections.

The RUNOFF and EXTRAN models of the combined sewered areas were developed and calibrated prior to the current study, as part of the City of Philadelphia's CSO permit compliance program. The watershed-wide model calibration for this work was based upon continuous simulation model comparisons with historic observed daily streamflow. A hydrograph separation technique was used to separate the baseflow and stormwater components of historic observed streamflow. Rainfall events of interest were identified for the period covered by both streamflow and rainfall data. Thunderstorms and winter storms were eliminated due to inadequate spatial rain gauge coverage. Simulated and monitored event volumes were compared and hydrologic parameters were adjusted to obtain a reasonable match across a range of storms as shown in Figure 12.3. Smaller storms were used to help calibrate depression storage, intermediate storms to calibrate DCIA, and larger storms to adjust soil parameters.

\subsubsection{RUNOFF Example}

Four of the five required BMP hydrologic and hydraulic processes can be represented in RUNOFF, because there is no slow release (e.g., through an orifice, riser, weir, or porous media). This may be acceptable for well-drained soils where infiltration alone is sufficient to remove water in a reasonable amount of time.

To simulate these BMPs, each RUNOFF subshed was separated into two parts as shown in Figure 12.4: 


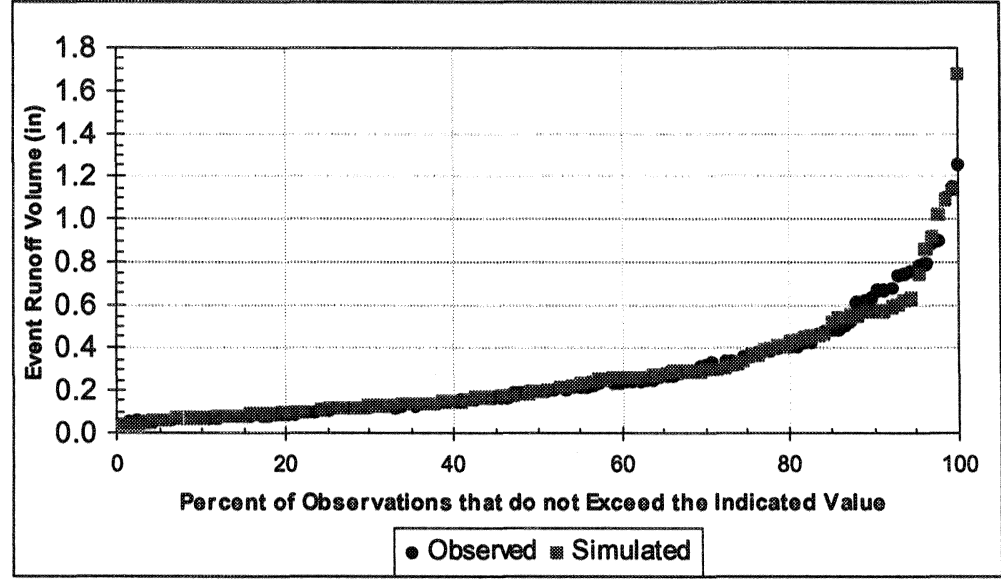

Figure 12.3 Example SWMM calibration plot.

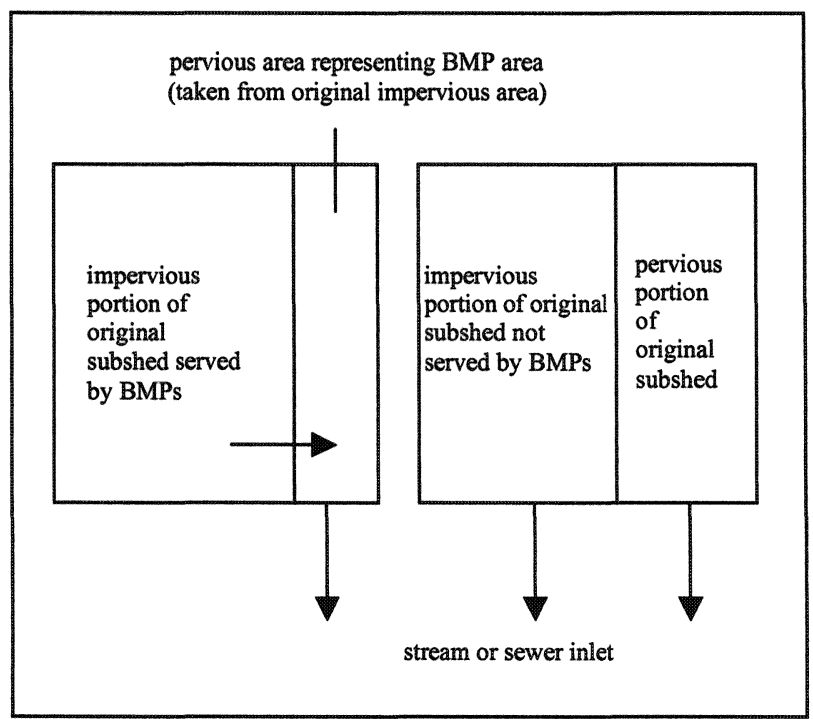

Figure 12.4 RUNOFF Model schematic diagram.

- one representing (i) the impervious portion of the original subshed that is not served by BMPs and (ii) the pervious portion of the original subshed, and

- one representing (i) the impervious portion of the original 
subshed that is served by BMPs and (ii) a pervious area representing the BMPs themselves. The BMP area is taken from the preexisting impervious area, thus reducing it. This area allows infiltration and evaporation. Any volume in excess of the available storage is routed instantaneously to the system outlet.

To gauge the appropriateness of this approach to modeling BMPs, the authors examined the sensitivity of runoff from a single subshed to changes in BMP area and the saturated hydraulic conductivity of soils in the BMPs. As shown in Figure 12.5, total runoff (BMP overflow) decreases with increasing impervious area draining to BMPs, and with increasing soil hydraulic conductivity $(\mathrm{K})$. The effects are linear for the types of soils present in the Cobbs Creek watershed, $(0.1$ to $0.5 \mathrm{in} / \mathrm{h}(2.54$ to $12.7 \mathrm{~mm} / \mathrm{h}))$.

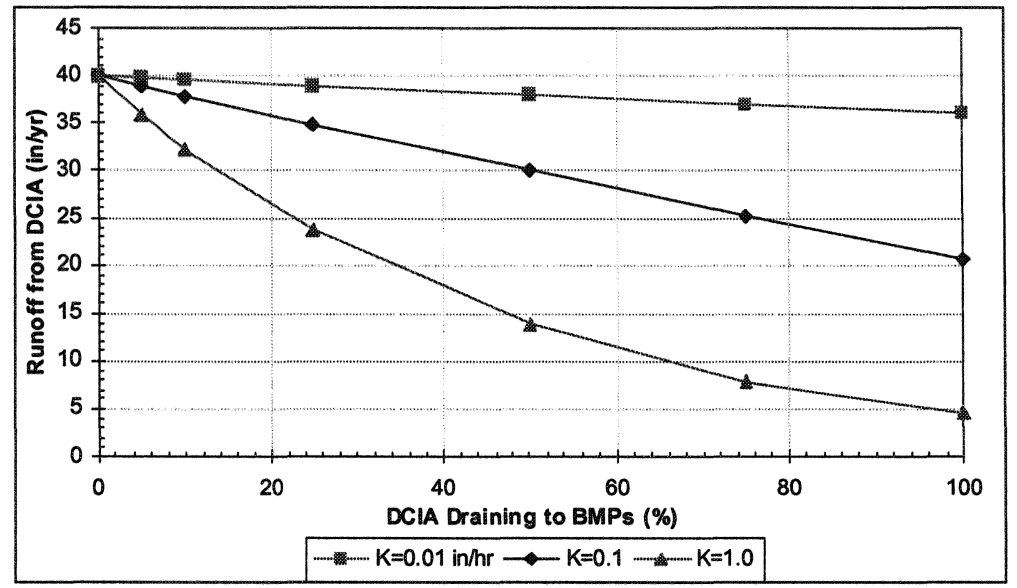

Figure 12.5 Sensitivity of surface runoff from one subshed to soil hydraulic conductivity (1000 sq.ft BMP per acre (20 $\mathrm{m}^{2} \mathrm{BMP}$ per ha) DCIA.); BMP volume $=1$ in. $(25 \mathrm{~mm})$ runoff from DCIA $)$

The authors performed a similar analysis on the effects of BMP area. A larger area allows increased evaporation and infiltration. As shown in Figure 12.6, the effect of BMP area becomes increasingly nonlinear with increasing size (to 20,000 sq. $\mathrm{ft} / 1,859 \mathrm{~m}^{2}$ ).

Figure 12.7 shows the decrease in untreated runoff as BMP elements are added to the entire system, which in an untreated condition has a DCIA of $30 \%$. The results for the watershed as a whole show a decrease in untreated runoff of almost $50 \%$ when the entire directly connected impervious area in the 


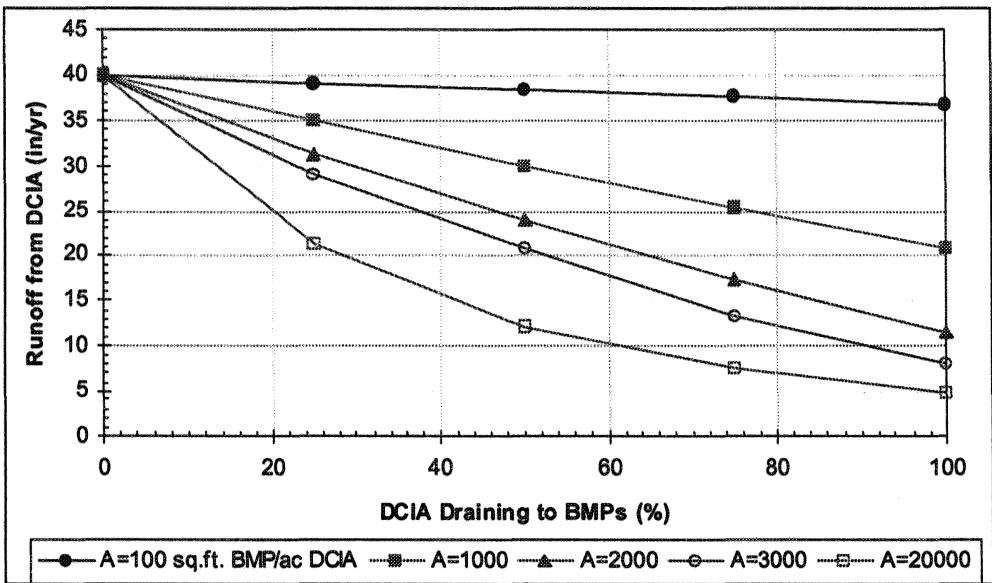

Figure 12.6 Sensitivity of surface runoff from one subshed to BMP surface area (saturated hydraulic conductivity $=0.1 \mathrm{in} .(3 \mathrm{~mm}) / \mathrm{h} ; \mathrm{BMP}$ volume $=1 \mathrm{in}$. (25 mm) runoff from DCIA)

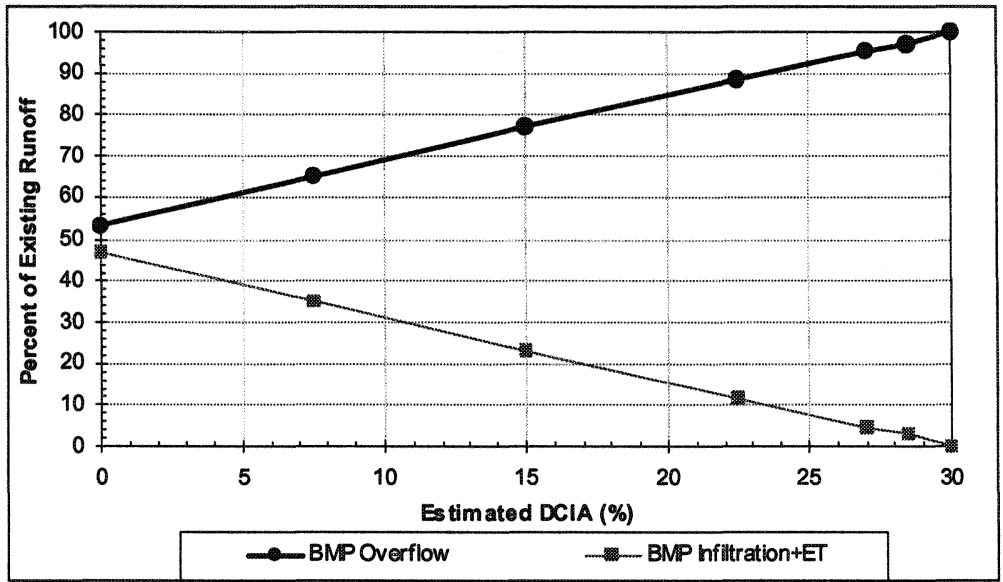

Figure 12.7 RUNOFF example: impervious area routed to pervious.

watershed is served by BMPs (DCIA is zero). The results for the system are consistent with the results of the single-subshed sensitivity analysis; the decrease in runoff is nearly linear given the soil hydraulic conductivity and size of the BMP elements.

The effects of adding BMP elements may be contrasted with the effects of removing impervious area entirely. In Figure 12.8, the points corresponding to 0 DCIA (all impervious cover removed but urban soils remaining) yield an 


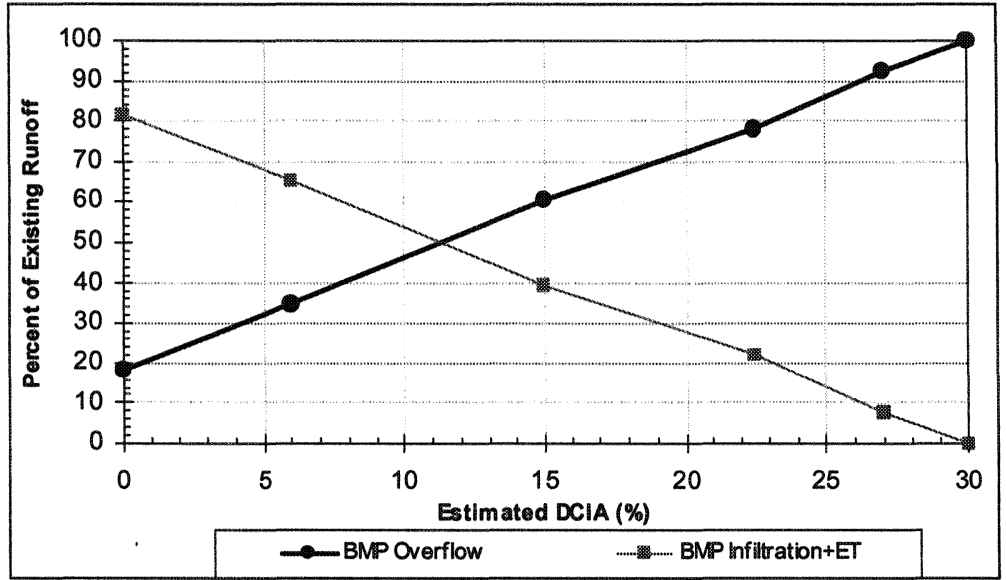

Figure 12.8 RUNOFF example: impervious area converted to pervious

$80 \%$ reduction in untreated runoff, compared to the $50 \%$ reduction when $\mathrm{BMP}$ elements are added. This result reinforces the idea that caution is warranted when determining how to represent the addition of stormwater controls in highly urbanized areas. The capacity of the BMPs to treat stormwater can have a significant impact in their watershed-wide effectiveness, and must be carefully considered when modeling.

\subsubsection{EXTRAN Example}

Figure 12.9 shows the results of a watershed-wide system of BMPs (conceptually, they may be thought of as infiltration basins) modeled using EXTRAN. The sizing of the elements is identical to that used in the previous RUNOFF example; the key difference is the additional line representing the portion of existing runoff that is detained and treated as DCIA is decreased.

In EXTRAN, it is possible to track three separate outflows from the BMP system: (i) untreated overflow or bypass flow; (ii) flow detained and treated by an orifice, riser, weir, or porous media; and (iii) the sum of infiltration and evaporation. To make the connection to water quality, it is possible when using EXTRAN to simulate BMPs to apply appropriate event mean concentrations (EMCs) to the overflow portion and to the treated portion to come up with pollutant load estimates. The flow and load estimates can then be added to a dynamic water quality model if desired. 


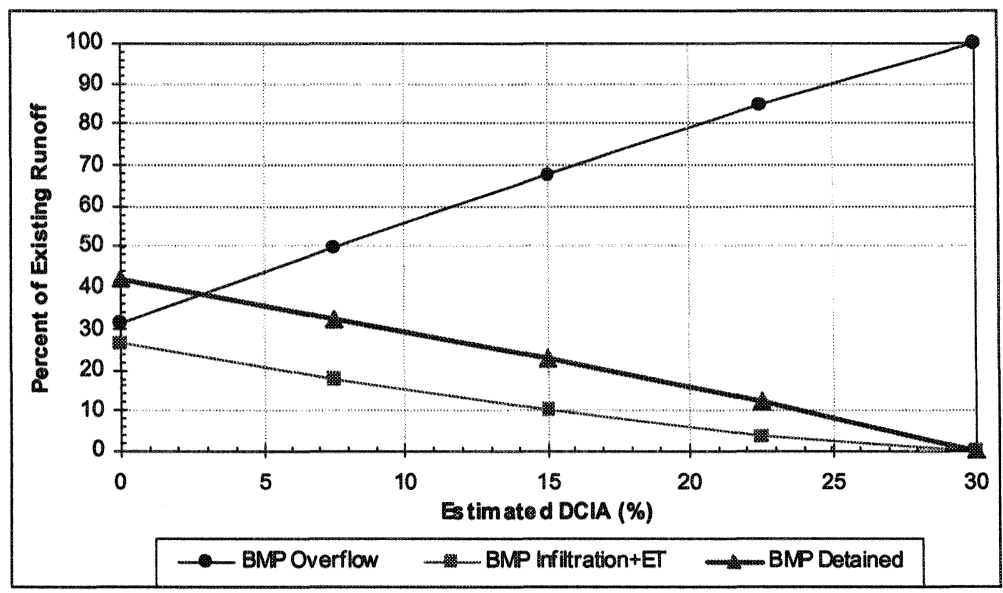

Figure 12.9 EXTRAN example.

\subsubsection{Discussion and Comparison}

The advantages of modeling using RUNOFF are relative ease of setup and debugging, short run times, ability to connect surface water and groundwater, and simulation of the physics of infiltration. The primary disadvantage is the inability to simulate a slow release through an orifice, weir, or riser. This slow release may be necessary to avoid long periods of standing water where the soil is not particularly well-drained.

The advantages of EXTRAN are the ability to simulate any combination of four of the five processes. The disadvantages are that it is relatively difficult to set up and debug, requires longer run times, does not simulate infiltration, and does not currently allow a connection to groundwater. Despite these disadvantages, the authors chose the EXTRAN approach as the best option to support certain structural BMPs in the Cobbs Creek watershed.

\subsection{Conclusions}

A significant aspect in watershed management planning is to examine the impacts of stormwater on streams, and to investigate ways to mitigate these impacts. Structural BMPs are an important tool for restoration of lost 
resources, and are required in many States and communities for all new development. BMPs in already urbanized areas, however, can also be effective in restoring some of the functions of urban streams. Installing BMPs in urban areas is expensive, and careful consideration of restoration goals and the feasibility of restoration is critical. This chapter demonstrates that modeling of BMPs in urban watersheds is feasible, and should play an important role in developing watershed management plans in urbanized areas. The primary conclusions form this study can be summarized as follows:

- most BMPs can be represented by a set of five common processes;

- SWMM is an appropriate tool for simulation of urban watersheds with complex hydrologic and hydraulic conditions, including combined sewer systems;

- a calibrated hydrologic and hydraulic model with added BMP elements is a powerful tool for decision making in long-term watershed planning; and

- SWMM provides a range of approaches for modeling BMPs. The tables in this chapter are a survey of approaches that may be taken in SWMMRUNOFF, STORAGE/TREATMENT, andEXTRAN.

\section{References}

American Society of Civil Engineers and U.S. Environmental Protection Agency. National Stormwater Best Management Practices (BMP) Database Version 1.2. http://www.bmpdatabase.org

American Society of Civil Engineers and U.S. Environmental Protection Agency. 2000. Determining Urban Stormwater Best Management Practice Removal Efficiencies: Final Data Exploration and Evaluation Report. EPA Assistance Agreement Number CX 824555-01 - Task 3.4.

Huber, W. and Dickinson, R. (1992). Stormwater Management Model, Version 4: User's Manual, Environmental Research Laboratory, Office of Research and Development, U.S. Environmental Protection Agency, EPA/600/3-88/001a. NTIS PB88-236641/AS. Athens, GA.

James, R., W. James and H. von Langsdorff. 2001. "Stormwater Management Model for Environmental Design of Permeable Pavement." Journal of Water Management Modeling R207-26. doi: 10.14796/JWMM.R207-26.

Roesner, L.A., J.A. Aldrich and R.E. Dickinson. 1988. Storm Water Management Model User's Manual, Version 4: Addendum I. EXTRAN; Cooperative Agreement CR-811607, U.S. EPA, Cincinnati, Ohio. 
Stirrup, M. and D. Marchant. 2002. "Simulation of a Combined Sewer Overflow Storage Tank." Journal of Water Management Modeling R208-17. doi: 10.14796/JWMM.R208-17. 